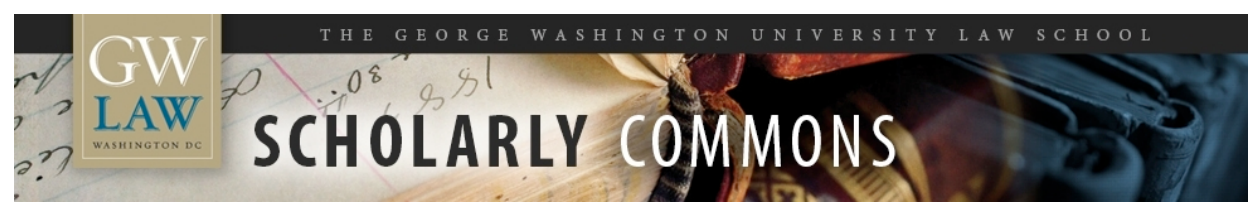

\title{
The Constitutional Structure and the Jurisprudence of Justice Scalia
}

Bradford R. Clark

George Washington University Law School, bclark@law.gwu.edu

Follow this and additional works at: https://scholarship.law.gwu.edu/faculty_publications

Part of the Law Commons

\section{Recommended Citation}

Bradford R. Clark, The Constitutional Structure and the Jurisprudence of Justice Scalia, 47 St. Louis U. L.J. 753 (2003).

This Article is brought to you for free and open access by the Faculty Scholarship at Scholarly Commons. It has been accepted for inclusion in GW Law Faculty Publications \& Other Works by an authorized administrator of Scholarly Commons. For more information, please contact spagel@law.gwu.edu. 


\title{
THE CONSTITUTIONAL STRUCTURE AND THE JURISPRUDENCE OF JUSTICE SCALIA
}

\author{
BRADFORD R. CLARK*
}

\section{INTRODUCTION}

Commentators generally regard federalism and separation of powers as distinct features of the constitutional structure. In reality, these doctrines were designed to work together to further the same goals: to avoid tyranny and to preserve individual liberty. Professor Thomas Merrill overlooks this connection in his attempt to explain the Supreme Court's decision making process under Chief Justice William Rehnquist. ${ }^{1}$ Professor Merrill maintains that there have been two Rehnquist Courts: one from 1986 to 1994, and another from 1994 to the present. In Professor Merrill's view, the first Rehnquist Court focused on social issues - such as abortion, affirmative action, and school prayer-with "relatively few important doctrinal innovations in these areas." 2 The second Rehnquist Court, by contrast, focused on "constitutional federalism, including the scope of federal power under the Commerce Clause and Section 5 of the Fourteenth Amendment, Tenth Amendment limitations on federal power, and state sovereign immunity from private lawsuits reflected in the Eleventh Amendment." Unlike the first Rehnquist Court, the second "has generated a number of important innovations."

Professor Merrill considers four hypotheses about judicial behavior in an attempt to explain these differences, including what he calls "the internal

* Professor of Law, George Washington University Law School. I thank Bill Kelley, John Manning, and Jon Molot for insightful comments and suggestions. I also thank John Kammerer and Brian Wesoloski for excellent research assistance.

1. See Thomas W. Merrill, The Making of the Second Rehnquist Court: A Preliminary Analysis, 47 ST. LoUIS U. L.J. 569 (2003).

2. Id. at 570 .

3. $I d$.

4. $I d$. 
strategic actor hypothesis." Applying this hypothesis, Professor Merrill suggests that Justice Antonin Scalia made a strategic choice to shift his priorities from social issues to constitutional federalism circa $1994 .{ }^{6}$ This hypothesis is unpersuasive. As Professor Merrill acknowledges, Justice "Scalia had little occasion to consider questions of constitutional federalism before he was appointed to the Supreme Court.", Thus, it is not surprising that Justice Scalia did not arrive on the Court with a full-fledged federalism agenda or that he preferred to wait for briefing and argument before reaffirming an important precedent like Hans v. Louisiana. ${ }^{8}$ From the beginning, however, Justice Scalia has been a strong proponent of constitutional federalism. In fact, with only one arguable exception, ${ }^{9}$ Justice Scalia has voted to uphold the constitutional prerogatives of the states in every major federalism case decided since he joined the Court.

Professor Merrill presents a variety of "circumstantial evidence" to support his thesis that Justice Scalia made a strategic choice to favor federalism in 1994. ${ }^{10}$ None of this evidence, however, withstands analysis. In fact, much of the evidence that Professor Merrill presents actually undercuts his hypothesis and confirms Justice Scalia's long-standing commitment to constitutional federalism. In the end, Professor Merrill fails to marshal any persuasive evidence to support his claim.

Justice Scalia does appear to have an "agenda" of sorts in federalism cases, although not the one that Professor Merrill suggests. Justice Scalia's goal in these cases is to uphold the original constitutional structure in order to respect the Founders' constitutional design and to protect individual liberty. Professor Merrill acknowledges Justice Scalia's interest in the constitutional separation of powers, ${ }^{11}$ but fails to recognize the connection between separation of powers and federalism. Neither feature of the constitutional structure was meant to be an end in itself. Rather, both separation of powers and federalism were designed to check government power and to secure individual liberty. As James Madison explained in urging ratification, because the Constitution both divides and separates power, "a double security arises to the rights of the people." 12 Thus, even though Justice "Scalia had little occasion to consider questions of constitutional federalism before he was appointed to the Supreme Court," 13 it is not surprising that he quickly came to regard federalism-like

5. Id. at 572 .

6. See Merrill, supra note 1, at 601-20.

7. Id. at 609 .

8. 134 U.S. 1 (1890). See infra notes 38-42 and accompanying text.

9. Welch v. Tex. Dep't of Highways \& Pub. Transp., 483 U.S. 468 (1987).

10. Merrill, supra note 1, at 609-17.

11. Id. at 604 .

12. The Federalist No. 51, at 323 (James Madison) (Clinton Rossiter ed., 1961).

13. Merrill, supra note 1 , at 609. 
separation of powers - as an essential element of the Founders' constitutional design.

\section{MERRILL's EVIDENCE}

Professor Merrill produces no persuasive evidence to support his claim that "Justice Scalia has behaved strategically in seeking to influence the entire course of the Rehnquist Court over the last eight years." relies exclusively on "circumstantial evidence" to support his hypothesis. ${ }^{15}$ Upon analysis, however, that evidence not only fails to support, but generally tends to refute, Professor Merrill's account.

First, Professor Merrill finds that nothing in Justice Scalia's background suggests an orientation favoring "devolution of power from the federal government to the states."16 Specifically, Professor Merrill notes that Justice Scalia's "entire professional career had been in federal service or in teaching federal administrative law at national law schools." 17 The mere fact, however, that Justice Scalia had few occasions to consider federalism questions before joining the Supreme Court yields no evidence - circumstantial or otherwiseof his views on the topic. Similarly, the fact that then-Professor Scalia's scholarly interests lay elsewhere provides no basis for predicting how he would later rule on federalism questions as a judge sworn to uphold the Constitution.

Second, Professor Merrill notes that Justice Scalia considered the question of federal sovereign immunity early in his academic career, and recognized that the doctrine "has little claim either to historical legitimacy or practical efficacy." 18 According to Professor Merrill, "[s]omeone harboring these views about federal sovereign immunity would be unlikely to give an unqualified endorsement to state sovereign immunity." 19 The very article that Professor Merrill cites, however, draws a sharp distinction between the legitimacy of federal and state sovereign immunity by differentiating "'domestic' and 'foreign' sovereign immunity." 20 According to Professor Scalia, "foreign" immunity provides "exemption from the compulsory process of another sovereign," whereas "domestic" immunity refers to "exemption of the state's executive or legislative branches from the compulsory process of its own judiciary." 21 Thus, as Professor Scalia explained, the "eleventh amendment to the Constitution embodies only that 'foreign' immunity, protecting the states

14. Id. at 604 .

15. Id. at $609-17$

16. Id. at 609 .

17. $I d$.

18. Merrill, supra note 1, at 610.

19. Id.

20. Antonin Scalia, Sovereign Immunity and Nonstatutory Review of Federal Administrative Action: Some Conclusions From the Public-Lands Cases, 68 MiCH. L. REV. 867, 886 (1970).

21. Id. 
from being sued before federal tribunals by citizens of other states or nations."22 The federal government, by contrast, has only "domestic" immunity from suit in federal court.

It is true, as Professor Merrill suggests, that Professor Scalia was critical of federal sovereign immunity. Such criticism, however, contrasts sharply with Professor Scalia's apparent willingness to embrace broad state sovereign immunity under the Constitution. For example, Professor Scalia criticized the Supreme Court's early practice of restricting Eleventh Amendment immunity to cases in which the state itself was the party of record. According to Professor Scalia, "[i]t eventually and inevitably became clear that the "party of record' test ... could not continue to be applied to the eleventh-amendment cases without flouting the clear intent of the Constitution." ${ }^{23}$ Professor Scalia's only lament was that this necessary expansion of state immunity spread to federal immunity as well. Thus, Professor Scalia complained that, during the nineteenth century, "the Supreme Court treated cases arising under the eleventh amendment as involving essentially the same issue as those cases which dealt with the 'domestic' immunity of the United States itself." 24 "Consequently," Professor Scalia explained, "a change made to protect the states from the federal courts, as the Constitution required, had the very different effect of insulating the federal government from the federal courts, thereby casting a shadow upon the entire field of nonstatutory review." 25 These observations reveal that, as early as 1970, Professor Scalia believed that state sovereign immunity had a greater claim to constitutional legitimacy than federal sovereign immunity. ${ }^{26}$

Third, Professor Merrill examines "Justice Scalia's pre-judicial attitude" with respect to "the more general topic of federalism.", 27 Specifically, Merrill discusses a four-page speech that Professor Scalia delivered to the Federalist Society in $1982 .^{28}$ Professor Scalia cautioned those in attendance against "generalized hostility towards national law which has become a common feature of conservative thought." ${ }^{29}$ Professor Merrill apparently (mis)reads this speech as hostile to constitutional federalism and treats it as circumstantial evidence of Justice Scalia's subsequent strategic behavior on the Supreme

22. Id.

23. Id. at 887 .

24. Id. at 886 .

25. Scalia, supra note 20 , at 888 (emphasis added).

26. See Peter J. Smith, States as Nations: Dignity in Cross-Doctrinal Perspective, 89 VA. L. REV. 1, 35 (2003) (discussing Professor Scalia's view that state sovereign immunity corresponds to foreign state immunity under the law of nations).

27. Merrill, supra note 1, at 610.

28. Antonin Scalia, The Two Faces of Federalism, 6 HARV. J.L. \& PUB. POL'Y 19 (1982).

29. Id. at 20 . 
Court. Professor Scalia, however, actually endorsed a broad vision of federalism, properly understood. He explained:

In meeting to discuss federalism, we have to bear in mind that it is a form of government midway between two extremes. At one extreme, the autonomy, the disunity, the conflict of independent states; at the other, the uniformity, the inflexibility, the monotony of one centralized government. Federalism is meant to be a compromise between the two. ${ }^{30}$

Thus, while recognizing the limited nature of federal power, Professor Scalia encouraged conservatives to use such power to achieve conservative ends. "When liberals are in power they do not shrink from using the federal structure for what they consider to be sound governmental goals. But when conservatives take charge, the most they hope to do is to keep anything from happening." 31

Professor Scalia's point was not that conservatives should disregard the constitutional limits of federal power. Rather, he merely suggested that they should use the federal government's undisputed power in constructive ways. For example, Professor Scalia cited "economic regulation" as "an area in which it is clear that the Founding Fathers meant the federal government to restrain the centrifugal tendencies of the states." 32 Professor Scalia specifically mentioned the possibility of preempting burdensome local cable regulations in order to implement a national free market policy. ${ }^{33}$ Such a proposal suggests no hostility to constitutional federalism. As Professor Scalia emphasized:

I do not think the most dyed-in-the-wool anti-federalist among you would deny that the federal government has power to establish the regulatory environment for cable-which is, realistically, part of an interstate delivery system that brings information and entertainment from the production studios of New York and California to the individual home. ${ }^{34}$

In the end, what Professor Merrill regards as evidence of hostility to federalism is, in reality, nothing more than a policy preference as to how the federal government should exercise its limited constitutional power. The mere fact that Professor Scalia urged federal protection of interstate cable operations tells us nothing about his view of Congress's power to prohibit local handgun possession near schools ${ }^{35}$ or to commandeer state and local law enforcement officers. ${ }^{36}$ Justice Scalia's subsequent resolution of these questions in favor of the states, however, is not surprising. In 1982, Professor Scalia expressly

\footnotetext{
30. Id. at 19 .

31. Id. at 20 .

32. Id.

33. Scalia, supra note 28 , at 21 .

34. Id.

35. See United States v. Lopez, 514 U.S. 549 (1995).

36. See Printz v. United States, 521 U.S. 898 (1997).
} 
rejected the "extreme" alternative of unlimited federal power and explained that "[f]ederalism is meant to be a compromise between" the "autonomy ... of independent states" and the "uniformity ... of one centralized government.",37

Fourth, Professor Merrill cites Justice Scalia's refusal during his first year on the Supreme Court to reconsider Hans v. Louisiana. ${ }^{38}$ In Welch v. Texas Department of Highways and Public Transportation, ${ }^{39}$ Justice Scalia wrote:

I find both the correctness of Hans as an original matter, and the feasibility, if it was wrong, of correcting it without distorting what we have done in tacit reliance upon it, complex enough questions that I am unwilling to address them in a case whose presentation focused on other matters. ${ }^{40}$

It is not surprising that Justice Scalia found "the correctness of Hans" to be a difficult question necessitating full briefing and argument. Even the most ardent proponent of constitutional federalism acknowledges that the immunity recognized in Hans must find its justification in sources beyond the text of the Eleventh Amendment. For present purposes, however, the important point is that Justice Scalia resolved this question in favor of the states when it next came before the Court in 1989-well before the 1994 fault line Professor Merrill hypothesizes. Accordingly, in Pennsylvania v. Union Gas Co., ${ }^{41}$ Justice Scalia voted to reaffirm Hans both on the basis of "the original meaning of the Constitution," and as a matter of stare decisis. ${ }^{42}$

Justice Scalia's resolution of this issue presents a serious "problem[] of timing"43 for Professor Merrill's thesis. As Merrill acknowledges, by 1989, "Justice Scalia had undeniably crossed the Rubicon on whether Congress has power to abrogate the Eleventh Amendment under its Article I powers, a proposition that forms one of the pillars of the federalism revolution of the second Rehnquist Court."44 This means that Justice Scalia embraced state sovereign immunity at least five years before Professor Merrill hypothesizes that a strategic actor in Justice Scalia's position would have made such a move.

There is additional evidence that Justice Scalia was a strong proponent of constitutional federalism throughout his tenure on the Supreme Court. For example, in his first year on the Court, Justice Scalia dissented in Tyler Pipe Industries, Inc. v. Washington State Department of Revenue, ${ }^{45}$ an otherwise routine negative Commerce Clause case. In the most sustained and sweeping challenge to the doctrine in modern times, Justice Scalia argued that the

37. Scalia, supra note 28 , at 19.

38. 134 U.S. 1 (1890).

39. 483 U.S. 468 (1987).

40. Id. at 496 (Scalia, J., concurring in part and concurring in the judgment).

41. 491 U.S. 1 (1989)

42. Id. at 34 (Scalia, J., concurring in part and dissenting in part).

43. Merrill, supra note 1, at 617.

44. Id. at 618 .

45. 483 U.S. 232 (1987). 
negative Commerce Clause "drastically limits the States' discretion" and "has no basis in the Constitution." $"$ According to Justice Scalia, the text of the Commerce Clause "is a charter for Congress, not the courts," to ensure free trade among the states. ${ }^{47}$ Justice Scalia observed that the "pre-emption of state legislation would automatically follow, of course, if the grant of power to Congress to regulate interstate commerce were exclusive." ${ }^{48}$ Justice Scalia rejected this reading, however, because unlike other provisions, "the language of the Commerce Clause gives no indication of exclusivity," 49 and "there is no correlative denial of power over commerce to the States in Art. I, $\S 10$, as there is, for example, with the power to coin money or make treaties." ${ }^{1,0}$ Justice Scalia also found that the "historical record provides no grounds" for the negative Commerce Clause. ${ }^{51}$ After reviewing the ratification debates, Justice Scalia thought "it beyond question that many 'apprehensions' would have been 'entertained' if supporters of the Constitution had hinted that the Commerce Clause, despite its language, gave this Court the power it has since assumed."

The same year, in Agency Holding Corp. v. Malley-Duff \& Associates, Inc. ${ }^{53}$ Justice Scalia was the only Justice to refuse to borrow a federal statute of limitations and apply it to civil RICO actions. Justice Scalia preferred to follow the Court's earlier "practice of borrowing state statutes," which he thought "in reality involved no borrowing at all." that "state statutes of limitations whose terms appear to cover federal statutory causes of action apply as a matter of state law to such claims," and that "imposition of limitations periods on federal causes of action is within the States' powers, if not preempted by Congress." 55

A few years later, in Tafflin v. Levitt, ${ }^{56}$ Justice Scalia urged the Court to reconsider its earlier dictum suggesting that state courts could be deprived of concurrent jurisdiction to hear federal claims even in the absence of an explicit federal statutory command to that effect. According to Justice Scalia, "[s]tate courts have jurisdiction over federal causes of action not because it is

46. Id. at 254 (Scalia, J., concurring in part and dissenting in part).

47. Id. at 260 .

48. Id. at 260-61.

49. Id. at 261.

50. Tyler Pipe Indus., Inc., 483 U.S. at 261.

51. Id. at 263.

52. Id at 264. Justice Thomas, joined by Justice Scalia, has also called on the Court to abandon the negative Commerce Clause. See Camps Newfound/Owatonna, Inc. v. Town of Harrison, 520 U.S. 564, 610 (1997) (Thomas, J., dissenting) ("The negative Commerce Clause has no basis in the text of the Constitution, makes little sense, and has proved virtually unworkable in application.").

53. 483 U.S. 143 (1987).

54. Id. at 158 (Scalia, J., concurring in the judgment).

55. Id. at 161 .

56. 493 U.S. 455 (1990). 
'conferred' upon them by the Congress," but because the laws of the United States constitute the law of the land applicable in federal and state courts alike. ${ }^{57}$ Thus, in Justice Scalia's view, it "takes an affirmative act of power under the Supremacy Clause" to deprive "state courts of their sovereign authority to adjudicate the law of the land." Duff, and Tafflin demonstrate that, contrary to Professor Merrill's assumption, Justice Scalia arrived on the Court with a strong commitment to upholding the states' prerogatives under the original constitutional scheme.

Fifth, Professor Merrill points to Justice Scalia's "voting record in preemption cases" as "circumstantial evidence tending to suggest the strategic nature of [his] behavior on constitutional federalism. $" 59$ He argues that

a sincere federalist would not only support formal limits on congressional power and immunities for states from suit by private citizens grounded in federal law, but he or she would also want to interpret the preemptive effect of federal statutes narrowly, so as to leave as large an ambit of state regulatory authority as possible. ${ }^{60}$

Yet, in Professor Merrill's view, Justice Scalia consistently supports "broad interpretations of the preemptive scope of federal law." ${ }^{\text {"1 }}$ Professor Merrill erroneously equates a commitment to upholding the constitutional division of power between the federal government and the states with an unyielding policy preference for state and local control. As Professor Scalia's 1982 speech to the Federalist Society illustrates, however, the Constitution's rejection of "one centralized government" $"$ does not mean that the federal government should hesitate to act in those areas in which "the Founding Fathers meant the federal government to restrain the centrifugal tendencies of the states."

Even putting aside Professor Merrill's false premise, his analysis of Justice Scalia's voting record in preemption cases suffers from significant methodological flaws. Merrill argues that Justice Scalia is an insincere federalist because in certain cases "Justice Scalia has supported federal preemption, but either Chief Justice Rehnquist or Justice Thomas (both of whom are more consistent supporters of states' rights) have voted against a

57. Id. at 469-70 (Scalia, J., concurring).

58. Id. at 470. The Court effectively adopted Justice Scalia's approach a few months later in Yellow Freight System, Inc. v. Donnelly, 494 U.S. 820 (1990). See Michael E. Solimine, Rethinking Exclusive Federal Jurisdiction, 52 U. PITT. L. REV. 383, 385 (1991) (stating that "the Court in Donnelly, perhaps influenced by Justice Scalia's concurring opinion in Tafflin, seemed more concerned with textual exegesis than with policy concerns in determining if the presumption of concurrent jurisdiction was rebutted").

59. Merrill, supra note 1, at 611 .

60. Id.

61. Id.

62. Scalia, supra note 28 , at 19.

63. Id. at 20 . 
finding of preemption." ${ }^{\text {,4 }}$ The cases that Professor Merrill cites, however, could just as easily be characterized as evidence of Justice Scalia's sincerity in federalism cases. Thus, in most of these cases, Justice Scalia voted with either Chief Justice Rehnquist or Justice Thomas - both sincere federalists according to Professor Merrill. If either of these "sincere" federalists found preemption, then there is no reason to question Justice Scalia's motive in such cases. Moreover, Professor Merrill does not take into account the votes of Justices O'Connor and Kennedy. Few would question Justice O'Connor's sincerity when it comes to federalism, ${ }^{65}$ and Professor Merrill himself suggests that Justice Kennedy may be a "more ardent states' rights advocate[], at least insofar as immunity from suit is concerned, than are" Justices O'Connor, Scalia, and Thomas. ${ }^{66}$ Thus, it is significant that either Justice O'Connor, or Justice Kennedy, or both, voted with Justice Scalia in almost every case that Merrill cites.

Sixth, Professor Merrill notes that Justice Scalia issued no separate concurring opinions "in the Court's post-Lopez federalism decisions." According to Merrill, this suggests that Justice Scalia "remains, at best, uninterested in issues of constitutional federalism." "68 This conclusion simply does not follow. Justices typically use separate concurring opinions to express disagreement, however small, with the Court's approach. Thus, the absence of concurring opinions by Justice Scalia is much more likely to signal agreement rather than disinterest. Consider the flag-burning cases, both of which were close 5-4 decisions. In Texas v. Johnson ${ }^{69}$ and United States v. Eichman, ${ }^{70}$ Justice Scalia joined Justice Brennan's majority opinions without writing separately. Before being elevated to the Supreme Court, Justice Scalia was not known for taking a particularly expansive view of the First Amendment. ${ }^{71}$ Yet no reasonable observer would conclude that Justice Scalia's failure to issue separate opinions in the flag-burning cases indicates either disinterest in free speech issues or insincerity in voting to invalidate the statutes at issue.

Seventh, Professor Merrill suggests that there is pronounced "tension between the new federalism and Justice Scalia's methodological convictions." ${ }^{, 72}$ For example, Professor Merrill asserts that "[b]oth the Tenth

64. Merrill, supra note 1, at 611-12 (emphasis added).

65. See id. at $608 \mathrm{n} .142$ and accompanying text (noting that Justice O'Connor had worked in state government and been active in state politics).

66. Id. at 611 n. 158 .

67. Id. at 612 .

68. Id.

69. 491 U.S. 397 (1989).

70. 496 U.S. 310 (1990).

71. See, e.g., Ollman v. Evans, 750 F.2d 970, 1036 (D.C. Cir. 1984) (en banc) (Scalia, J., dissenting).

72. Merrill, supra note 1, at 613. 
Amendment's anti-commandeering principle and the extension of the Eleventh Amendment to include actions in state court and before federal administrative agencies lack any foundation in the text of the Constitution." as evidence of strategic voting because "[i]n other contexts, such as substantive due process and the dormant Commerce Clause, Justice Scalia has been scornful of judicial doctrines that have no perceived foundation in the constitutional text." 74 Professor Merrill's argument rests on the false assumption that both sets of decisions require affirmative justification in the constitutional text. The original Constitution and the Tenth Amendment, however, suggest that the states retain all powers not prohibited to them by the Constitution, and that the federal government possesses only those powers "delegated to the United States by the Constitution." 75 Thus, doctrines restricting state power (like substantive due process and the dormant Commerce Clause) must be grounded in the text of the Constitution. Doctrines upholding state autonomy from federal interference, by contrast, frequently arise precisely because the Constitution is silent concerning the federal government's power to act. ${ }^{76}$

More fundamentally, Professor Merrill does not acknowledge that the text of the Constitution often fails to address matters implicit in the constitutional structure. As Charles Black explained, it would be "intellectually satisfying," but "not true," to say that, for constitutional law, our legal culture "always purports to move on the basis of the interpretation of particular constitutional texts." "77 Although searching "the written text for its meaning in application to the presented case" ${ }^{, 78}$ is the prevailing means of constitutional interpretation, Professor Black demonstrated that "the method of inference from the structures and relationships created by the constitution in all its parts or in some principal part" also plays a significant role "in the development of our constitutional law."79 Thus, even when "there is no constitutional text speaking to th[e] precise question, ${ }^{\prime 80}$ the constitutional structure frequently suggests an answer. Professor Merrill does not question Justice Scalia's sincerity in relying on the constitutional structure to decide separation of powers cases like Morrison $v$. Olson. ${ }^{81}$ There is no greater reason for doing so when Justice Scalia invokes

73. Id.

74. $I d$.

75. U.S. CONST. amend. X.

76. See Bradford R. Clark, Translating Federalism: A Structural Approach, 66 GEO. WASH. L. REV. 1161, 1187-97 (1998).

77. Charles L. Black, JR., Structure and Relationship in CONSTITUTIONAL LaW 7-8 (1969).

78. Id. at 5 .

79. Id. at 7-8

80. Printz v. United States, 521 U.S. 898, 905 (1997).

81. 487 U.S. 654 (1988). See Merrill, supra note 1, at 605. 
the constitutional structure to decide federalism cases like Printz v. United States. ${ }^{82}$

Professor Merrill finds additional tension between "the new federalism and Justice Scalia's methodological convictions" in several cases in which "the Rehnquist majority has engaged in a close analysis of whether Congress has made sufficient 'findings' to justify its exercise of legislative power" under the Commerce Clause and Section 5 of the Fourteenth Amendment. ${ }^{83}$ According to Professor Merrill, this "process-based review entails an extensive foray into legislative history and would seem to implicate all of the dangers of illegitimacy and manipulation that Justice Scalia has cited in opposing the use of legislative history to construe ambiguous statutes." ${ }^{, 4}$

Here again, the "tension" that Professor Merrill identifies is more apparent than real. As the Supreme Court made clear in United States v. Lopez, ${ }^{85}$ "Congress normally is not required to make formal findings as to the substantial burdens that an activity has on interstate commerce." ${ }^{86}$ Although Congress made no findings to support the statute invalidated in Lopez, the Court suggested that such findings might be useful to the extent that they "enable us to evaluate the legislative judgment that the activity in question substantially affected interstate commerce, even though no such substantial effect was visible to the naked eye." ${ }^{, 7}$ Five years later, the Court confirmed the limited role of congressional findings in United States v. Morrison. ${ }^{88}$ On this occasion, Congress made findings that sex-based violence affects interstate commerce, but the Court considered such findings insufficient to establish the constitutionality of the statute in question. ${ }^{89}$

The Supreme Court's limited use of congressional findings in Commerce Clause cases is fully consistent with Justice Scalia's reluctance to use legislative history to determine the meaning of ambiguous statutory texts. At most, the Court suggested that such findings might help the Court understand why Congress thought a particular statute fell within its constitutional power to enact. As Morrison demonstrates, however, congressional findings do not relieve the Court of its independent obligation to ascertain the meaning of the operative constitutional provisions. Textualists reject the use of legislative history as authoritative evidence of statutory meaning. ${ }^{90}$ Properly understood,

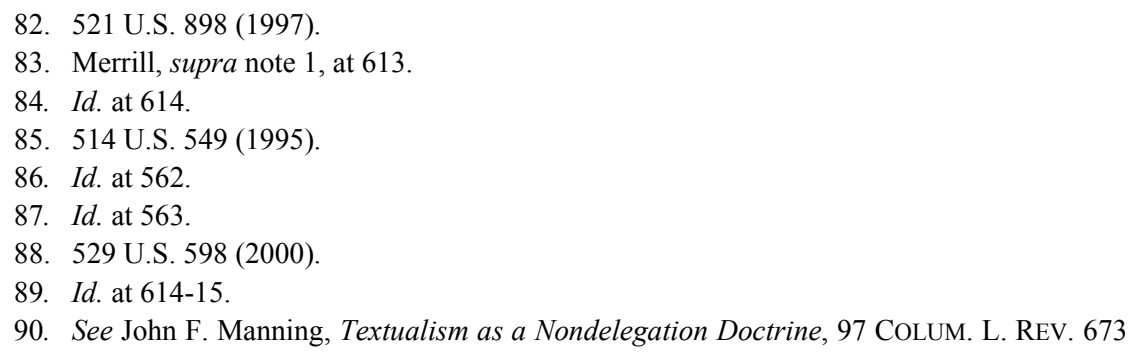


however, textualism "does not require the blanket exclusion of legislative history from judicial consideration." 11 Rather, so long as courts do not use legislative history to "give agents of Congress the power to "say what the law is," 92 such history "may add substantial value to the interpretive process by supplying a well-informed, contemporaneous account of the relevant background to the enactment." ${ }^{.93}$ Justice Scalia himself has relied on legislative history for just this purpose. ${ }^{94}$ Such reliance is consistent with the Rehnquist Court's willingness to consider congressional findings for analogous purposes in cases like Lopez and Morrison.

Eighth, Professor Merrill believes that "the content of the three states' rights opinions [Justice Scalia] has been assigned to write for the five-Justice majority" " is "consistent with the hypothesis that Justice Scalia's support for the Rehnquist majority in these cases is strategic." ${ }^{.96}$ Although acknowledging that such judgments are "necessarily subjective," Professor Merrill's impression is that "these opinions reflect relatively little enthusiasm or engagement with the immediate question at hand-constitutional federalism." ${ }^{97}$ For example, Professor Merrill characterizes Justice Scalia's opinion in Printz v. United States ${ }^{98}$ as "listless and defensive." that Scalia's "otherwise wooden opinion becomes animated only when discussing a structural reason for invalidating federal laws commandeering state officers, namely, that this 'shatter[s]' the principle of the unitary executive, thereby permitting Congress to reduce the power of the President." $" 100$

As an initial matter, I would dispute Professor Merrill's characterization of Justice Scalia's opinion. It is true that Printz does not simply restate Justice O'Connor's "clear theory" of government accountability from New York $v$. United States, ${ }^{101}$ which Professor Merrill apparently prefers. Justice Scalia, however, makes a significant contribution to the doctrine in the "many pages" that he spends "arguing against the proposition that the anti-commandeering

91. Id. at 732 .

92. Id. at 731. Giving agents of Congress such power would undermine an important feature of the constitutional structure. As John Manning has explained, "textualism should be understood as a means of implementing a central and increasingly well-settled element of the separation of powers - the prohibition against legislative self-delegation." Id. at 675 .

93. Id. at 732.

94. See United States v. Fausto, 484 U.S. 439, 444 (1988) (relying on a Senate report to confirm "[a] leading purpose" of the statute).

95. Merrill, supra note 1, at 614.

96. Id. at 617.

97. Id. at 614 .

98. 521 U.S. 898 (1997).

99. Merrill, supra note 1, at 614.

100. Id. at 615 .

101. 505 U.S. 144 (1992). 
principle of New York is contrary to historical practice and understandings.",102 Professor Merrill disparages Justice Scalia's reliance on "historical practice and understanding," but this inquiry is crucial in commandeering cases because the constitutional text is silent on the matter. ${ }^{103}$ Thus, Justice Scalia's focus on history was not only appropriate, but essential, to proper resolution of the question presented in Printz.

Professor Merrill also points to Justice Scalia's reliance on other aspects of the constitutional structure in Printz as evidence of strategic behavior. $\mathrm{He}$ argues that Justice Scalia "attempt[ed] to re-ground the anti-commandeering principle in the separation of powers doctrine of the unitary executive." 104 In Professor Merrill's view, such reliance on the separation of powers reveals Justice Scalia's "desire to use federalism cases to achieve other ends." 105 Professor Merrill's argument rests on the false assumption that there is no logical connection between the Constitution's separation of powers and federalism. In fact, many of the Supreme Court's most significant separation of powers decisions also safeguard federalism by preventing each branch of the federal government from circumventing federal lawmaking procedures designed to constrain federal action. ${ }^{106}$ Thus, if commandeering undermines the federal separation of powers, then that conclusion constitutes crucial evidence in determining whether the Constitution's otherwise ambiguous provisions affirmatively authorize Congress to commandeer the states.

Professor Merrill next cites Vermont Agency of Natural Resources $v$. United States ex rel. Stevens ${ }^{107}$ as an example of Justice Scalia's "desire to use federalism cases to achieve other ends." 108 He states that the Court took the case in order to resolve a circuit conflict over "whether the Eleventh Amendment bars an action against a state by an individual bringing a qui tam suit in the name of the United States." "109 After finding Article III standing, however, Justice Scalia's majority opinion avoided the Eleventh Amendment question by interpreting the term "persons" in the False Claims Act not to

102. Merrill, supra note 1, at 615 .

103. Clark, supra note 76, at 1195 (noting that with respect to commandeering "all potentially relevant provisions of the constitutional text... are ambiguous in the sense that they neither expressly confer nor expressly deny congressional power to take the challenged action").

104. Merrill, supra note 1, at 615.

105. Id. Justice Scalia also relied on the unitary executive to deny standing in Lujan $v$. Defenders of Wildlife, 504 U.S. 555 (1992). Using Professor Merrill's reasoning, such reliance would constitute evidence that Justice Scalia voted strategically to deny standing in order to further a distinct separation of powers agenda.

106. Bradford R. Clark, Separation of Powers as a Safeguard of Federalism, 79 TEX. L. REV. 1321, 1326 (2001).

107. 529 U.S. 765 (2000).

108. Merrill, supra note 1 , at 615 .

109. Id. 
include states. Professor Merrill finds it telling that in so doing Justice Scalia managed not to "say anything about federalism at all."

Professor Merrill fails to recognize, however, that the clear-statement requirement employed in cases like Vermont Agency itself constitutes an important doctrine designed to safeguard federalism. According to Justice Scalia, the Court's reading of the False Claims Act was buttressed by the rule that "if Congress intends to alter the usual constitutional balance between States and the Federal Government, it must make its intention to do so unmistakably clear in the language of the statute." 111 In support of this proposition, Justice Scalia cited Gregory v. Ashcroft, ${ }^{112}$ a case written by Justice O'Connor and generally counted among the Rehnquist Court's significant federalism decisions. The clear-statement requirement applied in such cases protects the governance prerogatives of the states by upholding state law unless "Congress actually considered - and proceeded to enact into law-a proposal that threatens state prerogatives."113 In other words, the doctrine ensures that the federal government incurs the decision costs imposed by federal lawmaking procedures - costs designed in large measure to preserve the states' ability to govern their own affairs. ${ }^{114}$

\section{SCALIA's STRATEGY}

Given that Professor Merrill's "internal strategic actor" hypothesis lacks meaningful support, one must look elsewhere to explain Justice Scalia's approach in federalism cases. Justice Scalia is an "originalist" when it comes to constitutional interpretation. The original Constitution "establishes a structure of government with two main features-federalism and separation of powers." 115 Professor Merrill assumes that separation of powers and federalism are mutually exclusive doctrines - that is, that commitment to one somehow precludes enthusiasm for the other. The Founders, by contrast, viewed these doctrines as mutually reinforcing features of the constitutional structure designed to serve the same ends. As James Madison explained:

In the compound republic of America, the power surrendered by the people is first divided between two distinct governments, and then the portion allotted to each subdivided among distinct and separate departments. Hence a double security arises to the rights of the people. ${ }^{116}$

110. Id. at 616 .

111. Vermont Agency, 529 U.S. at 787 (quoting Will v. Mich. Dep't of State Police, 491 U.S. $58,65(1989))$.

112. 501 U.S. 452 (1991).

113. Clark, supra note 106, at 1427.

114. Id. at $1338-46$.

115. Clark, supra note 76, at 1161.

116. The FedERAlist No. 51, at 323 (James Madison) (Clinton Rossiter ed., 1961). 
Justice Scalia supports federalism for the same reason that he embraces the separation of powers. Both doctrines are integral parts of the original constitutional plan to preserve individual liberty. ${ }^{117}$

Justice Scalia generally takes an "'originalist' approach to constitutional interpretation." "118 This approach attempts "to establish the meaning of the Constitution, in 1789," by "examining various evidence, including not only, of course, the text of the Constitution and its overall structure, but also the contemporaneous understanding" of the Founders, the background reflected in the English constitution, and the understanding revealed by "the various state constitutions in existence when the federal Constitution was adopted."119 Justice Scalia acknowledges both "that historical research is always difficult and sometimes inconclusive," 120 and that "almost every originalist would adulterate it with the doctrine of stare decisis." ${ }^{121}$ In the end, however, Justice Scalia concludes that originalism is "more compatible with the nature and purpose of a Constitution in a democratic system" than nonoriginalism. ${ }^{122}$ Thus, if one seeks to predict Justice Scalia's resolution of constitutional questions, the best indicator is likely to be the original understanding of the Constitution.

With respect to separation of powers, for example, Justice Scalia adheres closely to the Founders' view that "the preservation of liberty requires that the three great departments of power should be separate and distinct." 123 The Founders believed the legislative department to be the most dangerous threat to

117. Madison also linked federalism, separation of powers, and individual liberty at the Virginia Convention:

Consider fully the principles of the Government. The sum of the powers given up by the people of Virginia is divided into two classes. One to the Federal and the other to the State Government. Each is subdivided in three branches. These may be kept independent of each other in the one as well as the other. In this system they are as distinct as is consistent with good policy. This, in my opinion, instead of diminishing, increases the security of liberty more than any Government that ever was. For the powers of Government which in every other country are given to one body, are here given to two; and are favourable to public liberty.

Debates of the Virginia Convention (June 14, 1788), in 10 THE DOCUMENTARY HiSTORY OF THE RATIFICATION OF THE CONSTITUTION 1258, 1295 (John P. Kaminski \& Gaspare J. Saladino eds., 1993).

118. Antonin Scalia, Originalism: The Lesser Evil, 57 U. CIN. L. REV. 849, 851-52 (1989).

119. Id. at 852 .

120. Id. at 864 .

121. Id. at 861 .

122. Id. at 862 .

123. The Federalist No. 47, at 301 (James Madison) (Clinton Rossiter ed., 1961). See also Agrippa XVI, Mass. GaZetTe, Feb. 5, 1788, reprinted in 5 ThE Documentary History of THE RATIFICATION OF THE CONSTITUTION 863, 864 (John P. Kaminski \& Gaspare J. Saladino eds., 1998) ("It is now generally understood, that it is for the security of the people, that the powers of the government should be lodged in different branches."). 
the constitutional separation of powers. As Madison explained: "Its constitutional powers being at once more extensive, and less susceptible of precise limits, [the legislature] can, with greater facility, mask, under complicated and indirect measures, the encroachments which it makes on the co-ordinate departments." surprise that Justice Scalia has voted to invalidate congressional attempts to usurp or interfere with the constitutional functions assigned to the executive and judicial branches.

Two cases illustrate Justice Scalia's approach. In Morrison v. Olson, ${ }^{125}$ Justice Scalia voted to invalidate the Independent Counsel statute because it interfered with the President's ability to control the execution of federal law. In his now-classic dissent, Justice Scalia stressed that "[t]he purpose of the separation and equilibration of powers in general, and of the unitary Executive in particular, was not merely to assure effective government but to preserve individual freedom." "26 Thus, he refused to go along with the majority's "ad hoc approach to constitutional adjudication," preferring "to rely upon the judgment of the wise men who constructed our system, and of the people who approved it, and of two centuries of history that have shown it to be sound."127 Similarly, in Plaut v. Spendthrift Farm, Inc. ${ }^{128}$ Justice Scalia invalidated a congressional attempt to reopen judicial judgments after they had become final. Speaking on behalf of the Court, Justice Scalia explained that the Founders "lived among the ruins of a system of intermingled legislative and judicial powers," 129 and, therefore, crafted Article III to give "the Federal Judiciary the power, not merely to rule on cases, but to decide them."130

The Founders also believed that federalism-like separation of powerswould safeguard liberty. As Alexander Hamilton explained:

Power being almost always the rival of power, the general government will at all times stand ready to check the usurpations of the state governments, and these will have the same disposition towards the general government. The people, by throwing themselves into either scale, will infallibly make it

124. The FedERALIST No. 48, at 310 (James Madison) (Clinton Rossiter ed., 1961).

125. 487 U.S. 654 (1988).

126. Id. at 727 (Scalia, J., dissenting).

127. Id. at 734. See also Mistretta v. United States, 488 U.S. 361, 413 (1989) (Scalia, J., dissenting) (urging invalidation of binding sentencing "guidelines" promulgated by the United States Sentencing Commission because there is "no place within our constitutional system for an agency created by Congress to exercise no governmental power other than the making of laws").

128. 514 U.S. 211 (1995).

129. Id. at 219.

130. Id. at 218-19. 
preponderate. If their rights are invaded by either, they can make use of the other as the instrument of redress. ${ }^{131}$

Justice Scalia's embrace of constitutional federalism is not only consistent with, but affirmatively complements, his commitment to the separation of powers. For example, in his first major federalism opinion in 1989, Justice Scalia expressly tied state sovereign immunity to the preservation of individual liberty. In an opinion joined by Chief Justice Rehnquist, Justice O'Connor, and Justice Kennedy, Justice Scalia identified the principle of state sovereign immunity as "an essential element of the constitutional checks and balances." " Such immunity, he explained, serves to maintain the "constitutionally mandated balance of power between the States and the Federal Government" and thus implements the Founders' intent "to ensure the protection of our fundamental liberties." 133

Justice Scalia expressed these same themes again in Printz v. United States, ${ }^{134}$ arguably his most significant federalism opinion on behalf of the Supreme Court. Justice Scalia examined "the original understanding of the Constitution" 135 in order to determine whether Congress has constitutional power to require state executive officers to implement federal commands. After surveying the historical record, Justice Scalia examined "the structure of the Constitution." 136 He began with the observation that "[a]lthough the States surrendered many of their powers to the new Federal Government, they retained 'a residuary and inviolable sovereignty.",137 Justice Scalia explained that "[t]his separation of the two spheres is one of the Constitution's structural protections of liberty." "138 Thus, permitting Congress to impress state executive officers into federal service would threaten this feature of the constitutional

131. The Federalist No. 28, at 181 (Alexander Hamilton) (Clinton Rossiter ed., 1961).

Delegates to the state ratifying conventions expressed similar views. As one delegate explained:

Too much provision cannot be made against a consolidation [of the states]. The state governments represent the wishes and feelings and local interests of the people. They are the safe guard and ornament of the constitution - they will protract the period of our liberties - they will afford a shelter against the abuse of power, and will be the natural avengers of our violated rights.

Debates of the Massachusetts Convention (Jan. 19, 1788) (statement of Mr. Ames), in 6 THE DOCUMENTARY HISTORY OF THE RATIFICATION OF THE CONSTITUTION 1254, 1256 (John P. Kaminski \& Gaspare J. Saladino eds., 2000).

132. Pennsylvania v. Union Gas Co., 491 U.S. 1, 39 (1989) (Scalia, J., concurring in part and dissenting in part).

133. Id. (internal quotations omitted).

134. 521 U.S. 898 (1997).

135. Id. at 910 .

136. Id. at 918.

137. Id. at 918-19 (quoting THE FEDERALIST No. 39, at 245 (J. Madison) (Clinton Rossiter ed., 1961)).

138. Id. at 921. 
structure - and, hence, individual liberty - by "immeasurably" augmenting the power of the federal government at the expense of the states. ${ }^{139}$

Contrary to Professor Merrill's reading, ${ }^{140}$ Printz reveals that Justice Scalia - like the Founding generation - understood federalism and separation of powers not as unrelated or contradictory doctrines, but as complementary features of the constitutional structure designed to serve the same purpose: the preservation of individual liberty. As he explained in Printz: “Just as the separation and independence of the coordinate branches of the Federal Government serve to prevent the accumulation of excessive power in any one branch, a healthy balance of power between the States and the Federal Government will reduce the risk of tyranny and abuse from either front.",141 Justice Scalia expressly tied this understanding to that of the Founders by quoting Madison's "double security" passage from The Federalist. ${ }^{142}$

Given that Justice Scalia regards both separation of powers and federalism as mechanisms for preserving individual liberty, it is perhaps not surprising that he voted to reaffirm Hans v. Louisiana ${ }^{143}$ just one year after the Supreme Court decided Morrison v. Olson. ${ }^{144}$ As discussed, Justice Scalia viewed the Court's decision in Morrison to uphold the Independent Counsel statute as inconsistent with the Constitution's separation of powers, and, hence, a threat to individual liberty. ${ }^{145}$ As Professor Merrill points out, when Justice Scalia first joined the Court in 1986, he seemed "genuinely dubitante on the issue" of whether Hans should be overruled. ${ }^{146}$ Three years later, Justice Scalia resolved any doubts by reference to "the original meaning of the Constitution" and stare decisis. ${ }^{147}$ In voting to reaffirm Hans, Justice Scalia undoubtedly sought to uphold the Constitution's structural protection of individual liberty. Having seen the Court disregard the separation of powers in Morrison just a year earlier, Justice Scalia may have been especially eager to preserve federalism, the other principal feature of the constitutional structure "adopted by the Framers to ensure the protection of our fundamental liberties."148

139. Printz, 521 U.S. at 922 .

140. See supra notes 104-06 and accompanying text.

141. Printz, 521 U.S. at 921 (quoting Gregory v. Ashcroft, 501 U.S. 452, 458 (1991)).

142. Id. at 922. See supra text accompanying note 116.

143. 134 U.S. 1 (1890).

144. 487 U.S. 654 (1988).

145. See supra notes $125-27$ and accompanying text.

146. Merrill, supra note 1, at 611.

147. Pennsylvania v. Union Gas Co., 491 U.S. 1, 34 (1989) (Scalia, J., concurring in part and dissenting in part).

148. Id. at 39 (internal quotations omitted). 


\section{CONCLUSION}

Justice Scalia's commitment to the original understanding of the Constitution naturally leads him to embrace both federalism and separation of powers. Each doctrine is an essential feature of the original constitutional plan to prevent tyranny and safeguard individual liberty. Thus, it is entirely foreseeable that Justice Scalia - a self-described originalist-would seek to implement both features of the original constitutional structure. One might legitimately question the correctness of Justice Scalia's votes in particular cases, but the record simply does not support Professor Merrill's thesis that these votes were not sincerely cast. By embracing both federalism and separation of powers, Justice Scalia has simply attempted to uphold Madison's assurance that in "the compound republic of America," "a double security arises to the rights of the people." 
